\title{
Positive Criminology and Rethinking the Response to Adolescent Addiction: Evidence on the Role of Social Support, Religiosity, and Service to Others
}

\author{
Byron R. Johnson ${ }^{1, *}$, Matthew T. Lee ${ }^{2}$, Maria E. Pagano ${ }^{3}$ and Stephen G. Post ${ }^{4}$ \\ ${ }^{1}$ Baylor University, Waco, Texas 76798, USA \\ ${ }^{2}$ University of Akron, Akron, Ohio, USA \\ ${ }^{3}$ Case Western Reserve University, Cleveland, Ohio, USA \\ ${ }^{4}$ Stony Brook University, Stony Brook, New York, USA
}

\begin{abstract}
Adolescent addiction has emerged as a major public health problem. The greatest increase in alcohol and other drug use disorders can be found among youth. Concurrently, technological advances in policing coupled with aggressive prosecuting and sentencing practices have contributed to the growth of America's correctional system. The assertive response of policing, courts, and corrections, however, have not prevented the dramatic rise of adolescent addiction. Unfortunately, there is no national data tracking addicted youth in the criminal justice system to evaluate what works when it comes to youth with addiction. This article reviews justice system responses to adolescent offenders with addiction, and promising approaches engaging juveniles in programmatic components of Alcoholics Anonymous (AA). This study highlights the role of spirituality, service to others, and social support in maintaining sobriety, reducing arrests, and lowering recidivism for adolescents court-referred to treatment. Recommendations for improving the response to adolescent offenders with addiction are offered.
\end{abstract}

Keywords: Alcohol and drug use, recidivism, adolescents, social support, service, spirituality.

\section{INTRODUCTION}

Adolescent addiction is a major public health problem in the United States (Bouchery et al. 2011). Tragically, the greatest increase in alcohol and other drug use (AOD) disorders is among youth (SAMSHA 2014; Pagano 2013a: 60). Ease in access to harder street drugs including methamphetamines, the overabundance of prescription medications, and the increasing prevalence of marijuana enhance the conditions for youth to use controlled substances (Hurley and Mazor 2013). Drinking and drug use during adolescence curtails brain development and longevity. If AOD has not yet caused death from medical problems or overdose, it propels a downward life trajectory of school drop-out, increased criminal offending, and incarceration (Coleman and Cater 2005; Miniño, Xu, and Kochanek, 2010; Office of the Surgeon General 2007; Bonnie and O'Connell, 2004; Miller et al. 2007; Neighbors, Kempton, and Forehand 1992). In this electronic age, having a criminal record makes it challenging to get a job, and criminal background checks on the internet are routine.

Substance-involved offenders represent a significant portion of the prison population. Studies

*Address correspondence to this author at the Institute for Studies of Religion, Baylor University, Waco, Texas 76798, USA; Tel: 254-710-7555;

Fax: 254-710-1428; E-mail: Byron_Johnson@baylor.edu estimate that $63 \%$ of adults incarcerated for a drug offense met DSM-IV criteria for drug dependency or abuse (Mumola and Karberg 2006); 31\% of adult offenders on parole or supervised release from prison were current illicit drug users (SAMSHA 2014). Estimates of youthful offenders meeting DSM-IV criteria for an AOD use disorder are comparable $(60 \%$; SAMSHA, 2014), with $77 \%$ using AOD (mainly marijuana) in the past 6 months (McClelland et al. 2004a; McClelland et al. 2004b). The causes of the growth of the U.S. prison population continue to be vigorously debated, but drug offenses represent the single largest percentage increase (49\%) influencing the total prison population (Harrison and Beck, 2006).

\section{THE JUSTICE SYSTEM RESPONSE TO ADOLESCENT ADDICTION}

\section{Incarceration}

Incarceration has often been seen as the most efficient and simplistic solution to our nation's crime and drug-related problems. Offenders can easily be considered "out of sight and out of mind" when they are incarcerated. Historically, incarceration has been viewed as (1) a means of punishing offenders for their actions - guided by a philosophy of retribution and what criminologists have long referred to as "just deserts," (2) a vehicle simply to incapacitate offenders (i.e. offenders cannot harm others while they are 
incarcerated and isolated from society), or (3) a deterrent to future crime - the notion that justice will be administered swiftly and the punishment severe enough to prevent potential offenders from committing illegal behavior. Scholars and practitioners have long debated the pros and cons of philosophical orientations (i.e. retribution, incapacitation, or deterrence) toward punishment (Kennedy 2008). However, there has been little debate that correctional facilities exist primarily to remove offenders from society rather than prioritizing the goal of rehabilitation. Stated differently, the goal of reforming offenders has always been secondary to the goal of isolating prisoners from society for the public safety. Regrettably, a diverse group of observers now question whether either of these goals have been met (Travis, Western, and Redburn 2014).

It is true that addiction equally afflicts individuals "from Yale to jail," but a disproportionately large proportion of those incarcerated come from economically disadvantaged communities. Many inmates were raised in dysfunctional homes. The link between the incarceration of a parent and a variety of antisocial behaviors among their children is well documented (Glaze and Maruschak 2008). Children of prisoners are at-risk for alcohol and drug abuse, delinquency and crime, gang involvement, and subsequent incarceration (Krisberg 2001), having watched a parent model these behaviors (Hagan and Dinovitzer 1999). Some contend that incarceration may actually reinforce an entrenched, cyclical pattern of incarceration from one generation to the next (Turney and Wildeman 2013), which contributes to the growing prison population (Wildeman 2010). Rather than providing offenders with the opportunities and resources necessary to correct behaviors and achieve sobriety, incarceration offers only a temporary freeze on the drink-trouble cycle. Upon release, many exoffenders find themselves back in the same communities and circles of influence, and many (47$60 \%$ ) return to criminal activity (Durose, Cooper, and Snyder 2014; Langan and Levin 2002).

Adolescent illicit drug use and drug trafficking is a serious crime, the rise of which has increased the jail population to unsustainable proportions. While incarcerated populations are thought to be out of sight and mind, the reality is far different -- they cost U.S. taxpayers a great deal (Wakefield and Wildeman 2013; Wildeman 2014). When a person is incarcerated, taxpayers "pay" once for the person's sentence - in both social and economic terms - but if he or she is not successfully rehabilitated and reintegrated, taxpayers "pay" again for subsequent crimes, incarceration, and loss of economic activity (Wakefield and Wildeman 2013; Wildeman and Muller 2012; Wang and Wildeman 2011; Wildeman 2010; and Wildeman and Western 2010). The comprehensive cost of incarceration is unfortunately far more pervasive and consequential than many scholars and policy-makers have previously understood. For example, correctional budgets for state governments exceeded $\$ 46$ billion in 2010 (Sourcebook 2010). In comparison, the price tag for all correctional budgets in the U.S. in 1980 was approximately $\$ 4$ billion. And these figures represent underestimates since most prison budgets fail to include 1) other state agencies' expenditures on imprisonment, 2) inmate health care, 3) employee health insurance, and 4) pension contributions. Moreover, these figures do not include the budget for the Federal Bureau of Prisons, which exceeded more than $\$ 6.5$ billion for 2012 (LaVigne and Samuels 2012). Incarceration appears to prevent recidivism about half of the time - an unfortunate outcome for almost $\$ 50$ billion in financial obligation each year.

\section{Probation}

Probation is the most common judicial response to criminal or delinquent activity. Probation allows an offender to stay within the community but under the supervision of a probation officer. Approximately $61 \%$ of convicted adults are sentenced to probation, which translates into approximately 1 in 51 adults or 1.7 million adults under community supervision (Herberman and Bonczar 2014; SAMSHA 2014).

Juvenile probation is a sanction for youth adjudicated in court and is viewed as a way of diverting juvenile offenders - especially first-time offenders from the court system. Probation sentences vary in length and often require offenders to complete 60 hours or more of community service. Juveniles are typically assessed for their need of addiction treatment, family counseling, anger management, other social services, and court-referred for services as needed. Youth adherence to probation sentencing is typically monitored by an assigned probation officer and a case worker. Although juvenile probation is the most common sentence, how many youths each year receive this judicial response is unclear. The Office of Juvenile Justice and Delinquency Prevention (OJJDP), within the Department of Justice, is currently funding a study that will collect data to create useful, valid, reliable estimates of the number of juveniles on probation at a specific point in time to accompany the 
information that is recoded for incarcerated juveniles. The reality that we do not even know how many young people are on probation and the tracking of courtreferred services assigned is clearly problematic.

The advantages of a probation sentence over incarceration include allowing the offender to work in the community, earn money to support self and family, get social support from family and friends, and avoid exposure to offenders with extensive criminal histories (MacKenzie 2006). Moreover, probation is much less costly than incarceration. The disadvantages of a probation sentence over incarceration include: fear by community residents of offender continued criminal involvement; inconsistent probation sentences; and lax monitoring of offenders on probation. While one officer might report the failure to attend a therapy session as a probation violation, another might overlook the absence. Because caseloads tend to be so large, probation officers are not able to monitor adequately probationers that desperately need thoughtful, intentional, and sustained supervision (Petersilia 1997; MacKenzie 2006). Structure and strict governance often benefits youth, which tilts many judges to reluctantly opt for incarceration over probation (Morris and Tonry 1991).

\section{Drug Courts}

The emergence of crack cocaine in the mid-1980s had an unprecedented and dramatic impact on the nation's criminal justice system. In an effort to stem the street drug dealing-and the crime and violence associated with illegal drug use-arrests and prosecutions of drug offenders escalated dramatically, and penalties for the possession and sale of illegal drugs were toughened. As a result of this nationwide war on drugs, unprecedented numbers of drug offenders were arrested, charged with felonies, prosecuted, convicted, and incarcerated. Thus the rise of drug offenders entering the justice system, coupled with the widespread dissatisfaction with the simple sentencing option of prison or probation, led to the establishment of adult drug courts in the 1990s (King and Pasquarella 2009).

Because of the complex issues surrounding AOD use, juvenile court judges experienced many of the same frustrations the adult courts had faced in responding to youth substance-related offenses: long treatment waiting lists, disjointed service delivery, lack of family engagement, and no input into the nature or extent of treatment. Consequently, in the mid-1990s, a number of innovative juvenile courts started drug court dockets that focused on AOD problems. With over 3400 adult and juvenile drug courts in the U.S. in operation today (NIJ 2015), evaluation studies are needed to determine continued investment in this approach and the specific program components that motivate and sustain behavioral change.

A recent meta-analysis evaluated the effectiveness of 92 adult drug courts, 34 juvenile drug courts, and 28 DWI drug courts (Mitchell et al. 2012). Most adult drug courts showed greater reductions in recidivism among participants than non-participants, with a drop in recidivism from $50 \%$ to $38 \%$ lasting 3 years (Mitchell et al. 2012). Similar results were shown in another metaanalysis of 32 adult drug courts (MacKenzie 2006). Evaluations of DWI drug courts show mixed findings with some demonstrating effects in magnitude to those of adult drug courts. Evaluations of juvenile drug courts show only small reductions in recidivism (Mitchell et al. 2012). Further, few evaluations analyze outcomes other than recidivism to evaluate the impact of and compliance with court-referred services.

A paucity of evaluation studies have examined the effectiveness of drug courts among subgroups of offenders. The diverse range of participants accepted by drug courts makes it difficult to analyze practices nationwide, though it has been suggested that drug courts may not best serve those with the most serious addictions or use the hardest drugs, for whom more intensive and long-term inpatient treatment is indicated (Lutze and Wormer 2007; Wormer and Lutze 2010). Dirty urine screens and non-compliance to sentencing components result in sanctions of additional community service, fines, and ultimately jail time for multiple violations.

\section{Treating Juveniles as Adults}

In the 1980 s and 1990 s, legislatures in nearly every state expanded transfer laws that allowed or required the prosecution of juveniles in adult criminal courts. The assumptions behind expansion of transfer laws were that: 1) youth offenders would receive sentences in the adult criminal system which are harsher and more proportional to their crimes; and 2) the threat of harsher punishment would result in lowered juvenile crime rates. Because there are no national data sets that track youth who have been tried and sentenced in the criminal justice system, the impact of expanded transfer laws is difficult to assess. Currently, only 13 states make public cross-sectional snapshots of the 
annual count of transfers, and few provide offense profiles, demographic characteristics, or details regarding processing and sentencing (Griffin, Adams, and Firestine 2011).

The two evaluation studies conducted to date have not found evidence to support benefits from this judicial approach (Jensen and Metzger, 1994; Singer and McDowall, 1988). Juveniles sentenced as adults reoffended sooner and more often, committed more serious subsequent offenses, were more likely to be incarcerated, and to have longer jail stays than those treated in the juvenile system (Fagan 1996). Further, juveniles who received harsher penalties when tried as adults were not deterred from future illegal acts. The adult processing of youths in criminal court may result in more criminal acts than increasing public safety (Bishop 2000). A 6-year follow-up study found higher recidivism rates for most juveniles who were sentenced as adults (Bishop 2000). Feld and Bishop (2012) conclude that research on treating juveniles as adults has not yielded the desired impact, and may have caused more harm.

An extension of the argument for treating juveniles as adults has been the boot camp movement within juvenile corrections. Correctional boot camps, sometimes called intensive incarceration, utilize a military boot camp paradigm and exist in many states. These programs incorporate physical exercise, drills, ceremony, and uniforms in order to instill discipline and respect in offenders. A systematic review of 32 research studies on boot camps, however, concludes there is no statistical difference in recidivism between offenders who participated in boot camps and those who did not (Wilson, MacKenzie, and Mitchell 2008).

Another sentencing option for juveniles that became known as "Scared Straight" was a predecessor to correctional boot camps for juvenile offenders. Established in the 1970s, Scared Straight programs quickly developed throughout the United States as a means of deterring juvenile crime. These programs usually include visits by at-risk youth to adult prisons where youth hear about the harsh reality of prison life from inmates. The programs can involve tours of the facility, living the life of a prisoner for a full day, and aggressive "in-your-face" presentations by inmates. Decades of research, however, have shown that this approach is not only ineffective but may also encourage youth deviant behaviors (Lipsey 1992). Researchers at the Campbell Collaboration analyzed results from Evaluation of 9 Scared Straight programs showed an increase of up to $28 \%$ in crime in youth assigned to Scared Straight as opposed to the control condition (Petrosino, Petrosino, and Buehler 2004).

In sum, we know that incarceration, probation, juvenile drug courts, and treating juveniles as adults have not resolved youth crime or prevented the dramatic rise in AOD use. Consequently, shrinking correctional budgets and overcrowded jails have led to a renewed interest in finding alternative solutions that treat the disease of addiction in order to reduce recidivism and restore lives. Now, more than ever before, there is a need for cost-effective and evidencebased approaches that are successful in treating AOD use disorders among youth. But what do we know about the efficacy of treatment programs for addicted youth?

\section{THE EMERGING POSITIVE CRIMINOLOGY PERS- PECTIVE}

Recent research in an emerging sub-field labeled "positive criminology" (Ronel and Elisha 2011), suggests that more positive and restorative approaches - including those that foster social connectedness and support, service to others, spiritual experience, personal integrity, and identity change - may be more effective than the prevailing punitive tactics (Ronel and Segev 2015). Consistent with traditional and contemporary restorative justice practices, these approaches seek to develop active responsibility on the part of individuals who have been living a lifestyle of irresponsibility (Braithwaite 2005; Best and Aston 2015). From this perspective, correctional practices should be explicitly designed to promote virtue (for a creative example, see Cullen, Sundt, and Wozniak 2001). Thus, the goal of punishment is not to inflict pain or exact revenge but rather to reconstruct and make better (Thompson and Jenkins 1993). Although this is rare in our current system, a concrete example has been provided by a program at the Louisiana State Penitentiary (Angola), the largest maximum security prison in the United States. Once known as one of the most violent and corrupt prisons in America, Angola is now known for its many inmate-led churches and a fully operational seminary (launched in 1995). In recent years adjudicated juveniles from New Orleans are being given the option to serve their sentence at Angola and to participate in a unique mentoring project. Robson (quoted in Hallet et al. 2015:13) observed that this restorative, faith-based program effectively: 
...de-institutionalizes the dehumanization of punitive justice [because it gives a person] the responsibility of making the right choices for the right reasons. Whereas dehumanization within a punitive system demands simply making choices for the wrong reasons-because they fear punishment [emphasis in the original].

This highlights Braithewaite's (2005: 291) crucial distinction between the passive responsibility inherent in the phrase "serving time," and which implies the state holding a person accountable for their past actions, and the active responsibility at the heart of restorative justice processes which focuses on "taking responsibility for putting things right into the future." This active responsibility is brought about by a "redemption script" (Maruna 2001:85-87) that allows a person to claim a "coherent and convincing" narrative supporting a significant identity transformation: from a selfish delinquent and/or addict to a responsible and helpful "new person." Rather than viewing the person as a set of risks to be managed, or a bundle of needs to be met, the person is understood to have strengths that can be deployed for the benefit of self and others (Maruna and Label 2003). The paradigm case is the "wounded healer:" a former addict who is uniquely effective in helping other addicts precisely because of prior experience in active addiction and addiction recovery.

While medicine has recognized addiction as a chronic, lifetime disease since the 1950's, the correctional system has been slow to adopt this view and modify sentencing to facilitate disease remission. Yet with recent legislation changes, non-violent youth offenders are increasingly being referred to addiction treatment and/or mandated attendance at 12-Step meetings as an alternative to incarceration. Chen and Gueta (2015), argue that 12-Step programs like Alcoholics Anonymous (AA) are simply practical applications of positive criminology. The 12-Step program is based on the notion that substance abuse is a multi-dimensional disorder affecting individuals at the physical, mental, and spiritual levels, and therefore requires a holistic recovery approach (Chen 2010). This view of the process of recovery is consistent with the comprehensive perception of the positive criminology approach (Chen and Gueta 2015).

While 12-Step research among adolescents is in its infancy, we are beginning to understand the mechanisms of behavioral change within $A A$ that can guide what we enforce in judicial sentencing. In order to illustrate these mechanisms, we turn to encouraging empirical results from the Service to Others in Sobriety (SOS) project, the largest longitudinal study to date of treatment-referred juvenile offenders with equal gender proportions. We discuss key findings from this study in the context of 12-step theory and positive criminology, and conclude with several recommendations for juvenile justice reform.

\section{A REVIEW OF RECENT RESEARCH ON ADOLESCENTS AND ADDICTION}

Project SOS enrolled 195 youth court-referred to a 2-month residential treatment program who were interviewed at intake, discharge, 6-months, and 12months post treatment. We refer readers elsewhere for a detail description of the study design, methods, and sampling (Kelly et al. 2011). Findings to date point to social variables as exerting a significant influence on adolescent drinking/drug use. Social anxiety disorder is the most common co-occurring anxiety disorder with AOD use disorders (Buckner et al. 2008; Zimmerman et al. 2003). For every 5 youth admitted into treatment, at least 2 youth (42\%) reported a persistent fear of being humiliated or scrutinized in social situations. While some might view being socially anxious as harmless, it appears to be linked to heroin use which is plaguing non-urban youth and girls in particular (Cicero et al. 2014). Social anxiety was associated with greater use of harder drugs (heroin), an earlier age of first use, and increased the risk of relapse post-treatment. Approximately one out of four youths endorsed feel estranged from others, which increased their risk of relapse, incarceration, and committing a violent crime in the 12-months post-treatment (Johnson et al. 2015). Addicts frequently describe a pervasive sense of not fitting it, acute sensitivity to others' opinions, and terrible loneliness that AOD temporarily silences.

Twelve-step theory provides a framework for realizing problematic ways the substance abuser relates to others that underlies addiction, and more importantly, a solution shown to work that is free and is widely accessible. Courts may be ahead of the curve in the practice of mandating meeting attendance for substance-related offenses; most providers also recommend meeting attendance, which is not part of formal treatment. Self-absorbed thinking -- expressions of which include grandiosity, hypersensitivity, or low self-worth -- is posited as a root cause of addiction. When the consequences of AOD use become great enough, the alcoholic must 1) find a power source to 
live by and 2) daily correct skewed thinking that (s)he wakes up with regardless of length of time sober. The 12-steps are designed to enable an alcoholic to find a Higher Power of his/her own understanding. Getting active in service is encouraged from day one of sobriety as the antidote to correct self-centered thinking that eventually leads back to active addiction.

There is evidence from Project SOS supporting this framework. For those who are active in service during treatment, it cuts the risk of relapse in half in the high risk period following treatment (Pagano et al. 2013a). Other evidence suggests helping others reduces depression that is common in early recovery (Pagano et al. 2009), fosters awareness of others (Pagano et al. 2013b), and provides a blueprint for positive selfidentity and social integration among offenders (Hallett 2015). In Project SOS, high helpers were also less likely to be incarcerated or to commit a violent crime in the year post-treatment. Interestingly, evidence showed that youth behavioral changes in AOD use and crime were tied to giving rather than receiving support in AA. Service participation was also linked to increases in spirituality, which increased in the sample overall during treatment. Specifically, $40 \%$ of youth entering treatment as agnostic or atheist identified themselves as spiritual or religious at discharge (Lee et al. 2014). There was also evidence for AA's assertion that "faith without works is dead," meaning faith only is insufficient for personal transformation. Increases in spirituality did not translate into greater improvement in posttreatment outcomes. However, increased spirituality combined with high service magnified the effects of service on reduced theft, burglary, and vandalism (Lee et al. 2016). Importantly, increases in either of these virtues did not depend on particular youth characteristics, including gender, race, religious orientation, severity of addiction, or criminal involvement. Higher service participation among youth with social anxiety and greater religious background suggest particular application among these subgroups (Pagano et al. 2015).

\section{RECOMMENDATIONS FOR JUVENILE JUSTICE REFORM}

Juvenile drug courts have had minimal impact in reducing recidivism and youth deaths from heroin overdoses are an epidemic nationwide. We recognize that judicial reform for young adult offenders with addiction is not a simple matter. Much depends upon the training, skills, and compassion of judge and judicial staff, knowledge of available community resources, the coordination of community services for youth and their families, monitoring of youth behavior, and a flexible incentive structure of rewards and sanctions to hold youth steady in recovery and from returning to deviant peer groups and criminal activity. Yet the call for justice system reform is growing louder. Citizens, practitioners, governmental officials, scholars, and policy experts stand united in the concern of the growing burden created by the traditional responses of the juvenile justice system (incarceration, probation, and drug courts). Justice system reform must include (1) performance measures that hold the system accountable for results (e.g., lowering crime rates and reducing re-offending); (2) prioritizing among offenders personal responsibility, work, community service, and treatment; (3) harnessing the power of families, charities, faith-based groups, and communities to reform amenable offenders; and (4) fostering costeffective approaches as well as reward results (Statement of Principles 2011). We discuss several recommendations that hold promise for achieving these goals. We consider the burden first from the incoming flow of young offenders with addiction facing arraignment and then make some suggestions for reform among those convicted behind bars.

\section{Prioritizing Treatment Over Incarceration}

There are positive developments within juvenile corrections that might be expanded across state jurisdictions. Judge Stanley Goldstein's vision of trading jail for treatment that initiated the first Drug Court in South Miami is today a model court for the country. In operation for more than two decades, many of the kinks have been worked out for a fluid system that graduates $50+$ recovering offenders each month. Outcomes for offenders and the services they receive should be tracked over time and made available in public datasets, and the results of these efforts should be published in scientific journals. Future funding should be based on rigorous and objective research. Policymakers should use published results to identify a portfolio of evidence-based policies that can demonstrate addiction can be reduced and that taxpayer money can be used effectively and efficiently. For example, findings from Project SOS highlight the contextual social variables that influence drinking and drug use. Low-cost, sustainable approaches that further social connectivity and integration into sober communities should be considered. For example, sentencing violations might be given sanctions for giving service at 12-step meetings instead of community service hours. Assisting service activities at 
meetings can provide a platform for youth to get to know sober peers in their community, while addressing the social isolation and self-absorbed thinking that characterizes the disease. Getting young offenders active in 12-step service can engage them as cocreators of solutions and help youth to be actively responsible in maintaining their disease in remission. Service activities may have particular application for youth with social anxiety, who are much less likely to participate in therapeutic activities that they otherwise perceive as carrying the risk of negative peer appraisal. As much as possible, these kind of community treatment programs should be highlighted and prioritized as viable alternatives to incarceration.

\section{Reconstruction of Young Afflicted Lives in Jail}

For those young people who do end up incarcerated, there is hope. Community volunteers are value added for correctional entities because they provide a host of services (e.g., mentoring, literacy, lifeskills, etc.) and research has shown that these volunteers are helpful in reducing recidivism (Bales and Mears 2008; Duwe and Johnson 2016). For example, groups like Prison Fellowship, Kairos, Alpha, Salvation Army, Alcoholics Anonymous, Delancey Street, and many others, provide a no-cost, low intensity pathway to such service (and other spiritual virtues) and could provide the institutional infrastructure that is needed to support a theoretically coherent set of evidence-based policies consistent with a positive criminology approach. Additionally, it is important to note that faithbased communities already provide the bulk of community volunteers working with offenders within correctional facilities (Duwe and Johnson 2016).

Faith-based activities in jails and other correctional facilities are very popular. For example, beyond work, education, or vocational training, religious activities attract more participants than any other personal enhancement program offered inside a prison (Beck and Shipley 1989). These programs foster increased spirituality that is linked to greater personal change when combined with service. Moreover, AA is already in existence in most prisons and other correctional institutions. Religious activities could easily be expanded to allow inmates time and instruction for completing the steps, which are designed to help an alcoholic gain access to a Higher Power.

The sheer pervasiveness of religious programs within correctional institutions provides an opportunity to better utilize these positive criminology approaches.
In addition, AA provides a platform and ready-made environment to make addiction treatment more accessible to offenders in various kinds of correctional facilities. Indeed, for those who are incarcerated, AA has been able to produce results at least as good as those in treatment (Forcehimes and Tonigan 2008; Tonigan and Bogenschutz 2008; Straussner and Byrne 2009).

In the last several decades, adolescent addiction has emerged as a major public health problem in the United States. At the same time, the massive reliance on incarceration and other justice system alternatives has not reduced the dramatic rise in adolescent AOD use disorders. More than ever, we are in need of costeffective and efficacious alternatives to traditional responses of the criminal and juvenile justice systems. Treatment approaches focus primarily on providing help to clients (e.g., skill acquisition, social support, or pharmacological treatments), but it may be equally if not more important to get clients active in service in the short window of their judicial sentencing when they are motivated to change their behavior. Service offers a nonjudgmental, task-focused venue for developing sober networks in youths' transition back into the community. Rather than the usual sentences imposed for youthful offenders with addiction, it is important to mandate or require they attend AA three times a week as adjunct treatment and be involved in service at these meetings. In an era of shrinking budgets, the policy implications are clear: we need to capitalize on existing free programs and build on them.

\section{REFERENCES}

Bales W. D. and D. P. Mears. 2008. "Inmate Social Ties and the Transition to Society: Does visitation reduce recidivism?" Journal of Research in Crime and Delinquency, 45: 287-321. http://dx.doi.org/10.1177/0022427808317574

Beck, A. J. and B. Shipley. 1989) Recidivism of Prisoners Released in 1983. Bureau of Justice Statistics. Recidivism of Released Prisoners Series, NCJ 116261.

Best, D. and E. Aston. 2015. "Long-term Recovery from Addiction: Criminal Justice Involvement and Positive Criminology." Pp. 177-193 in Positive Criminology, edited by Natti Ronel and Dana Segev. New York: Routledge.

Bishop, D. 2000. "Juvenile Offenders in the Adult Criminal System," in Michael Tonry (Ed). Crime and Justice. Volume 27: 81167.

http://dx.doi.org/10.1086/652199

Bonnie, R. J., \& M. E. O'Connell. 2004. Reducing Underage Drinking: A Collective Responsibility. Washington, DC: National Academies Press.

Bouchery, E. E., H. J. Harwood, J. J., Sacks, C. J., Simon, and R. D. Brewer, R. D. 2011. "Economic Costs of Excessive Alcohol Consumption in the United States, 2006." American Journal of Preventive Medicine 41: 516-524. http://dx.doi.org/10.1016/j.amepre.2011.06.045 
Braithwaite, J. 2005. "Between Proportionality \& Impunity: Confrontation, Truth, Prevention." Criminology 43:283-305. http://dx.doi.org/10.1111/j.0011-1348.2005.00009.x

Buckner, J. D., N. B. Schmidt, A. R. Lang, J. W. Small, R. C. Schlauch, and P. M. Lewinsohn. 2008. "Specificity of Social Anxiety Disorder as a Risk Factor for Alcohol and Cannabis Dependence." American Journal of Psychiatric Research 42: 230-239. http://dx.doi.org/10.1016/j.jpsychires.2007.01.002

Chen, G. 2010. "The Meaning of Suffering in Drug Addiction and Recovery from the Perspective of Buddhism, Existentialism and the 12 Step." Journal of Psychcoactive Drugs 42: 363375.

http://dx.doi.org/10.1080/02791072.2010.10400699

Chen, G. and K. Gueta. 2015. "Application of Positive Criminology in the 12-Step Program." Pp. 208-220 in Positive Criminology, edited by Natti Ronel and Dana Segev. New York: Routledge.

Cicero, T. J., M. Ellis, H. Surrat, and S. Kurtz. 2014. "The Changing Face of Heroin use in the United States." JAMA Psychiatry 71(7): 821-826.

http://dx.doi.org/10.1001/jamapsychiatry. 2014.366

Coleman, L. and S. Cater. 2005. "Underage 'Binge' Drinking: A Qualitative Study into Motivations and Outcomes." Drugs: Education, Prevention \& Policy 12: 125-136. http://dx.doi.org/10.1080/09687630512331323521

Coleman, L. and S. Cater. Recidivism of Prisoners Released in 30 States in 2005: Patterns from 2005 to 2010, Bureau of Justice Statistics Special Report, U. S. Department of Justice, Office of Justice Programs, NCJ 244205.

Cullen, F. T., J. Sundt, and J. Wozniak, J. 2001. "The Virtuous Prison: Toward a Restorative Rehabilitation." Pp. 265-286 in H. N. Pontell and D. Shichor (eds.), Contemporary Issues in Crime and Criminal Justice: Essays in Honor of Gilbert Geis. Upper Saddle River, NJ: Prentice Hall.

Drug C. 2015. National Institute of Justice, Bureau of Justice Assistance, and Office of Juvenile Justice and Delinquency Prevention, Office of Justice Programs, Department of Justice, Washington, DC.

Duwe, G. and B. R. Johnson. 2016. "The Effects of Prison Visits from Community Volunteers on Offender Recidivism." The Prison Journal 96: 279-303. http://dx.doi.org/10.1177/0032885515618468

Fagan, J. 1996. "The Comparative Advantage of Juvenile vs. Criminal Court Sanctions on Recidivism Among Adolescent Felony Offenders." Law and Policy 18:77-112. http://dx.doi.org/10.1111/j.1467-9930.1996.tb00165.x

Feld, B. C. and D. Bishop. 2012. Transfer of Juveniles to Criminal Court. Pp. 801-842. In B. C. Feld and D. M. Bishop (Eds.), The Oxford Handbook of Juvenile Crime and Juvenile Justice. New York: Oxford University Press.

Forcehimes, A. and J. S. Tonigan. 2008. "Self-efficacy to remain abstinent and substance abuse: A Meta-Analysis." Alcoholism Treatment Quarterly 26(4): 480. http://dx.doi.org/10.1080/07347320802347145

Glaze, L. and L. M. Maruschak. 2008. Parents in Prison and Their Minor Children. Bureau of Justice Statistics, Special Report, Washington, DC: U. S. Department of Justice, Office of Justice Programs.

Griffin, P., S. Addie, B. Adams, and K. Firestine. 2011. "Trying Juveniles as Adults: An Analysis of State Transfer Laws and Reporting." Juvenile Offenders and Victims: National Report Series. Washington, DC: Office of Juvenile Justice and Delinquency Prevention.

Hagan, J. and R. Dinovitzer. 1999. "Collateral Consequences of Imprisonment, Communities and Prisoners," in M. Tonry and J. Petersilia (eds.). Crime and Justice, Volume 26. Chicago, IL: University of Chicago Press.
Hallett, M., J. Hays, B. R. Johnson, S. J. Jang, and G. Duwe. 2015. "First Stop Dying": Angola's Christian Seminary as Positive Criminology." International Journal of Offender Therapy and Comparative Criminology. http://dx.doi.org/10.1177/0306624X15598179

Harrison, P. and A. Beck. 2006. US Department of Justice, Bureau of Justice Statistics, Prisoners in 2005 (Washington DC: US Department of Justice, NCJ 215092).

Herberman, E. J. and T. P. Bonczar. 2014. "Probation and Parole in the United States, 2013." Washington, DC: US Department of Justice Bureau of Justice Statistics, NCJ248029.

Hurley W. and S. Mazor. 2013. "Anticipated Medical Effects on Children from Legalization of Marijuana in Colorado and Washington State: A Poison Center Perspective." JAMA Pediatrics. 167 (7): 602-3. http://dx.doi.org/10.1001/jamapediatrics.2013.2273

Jensen, E. L. and L. K. Metsger. 1994. "A Test of the Deterrent Effect of Legislative Waiver on Violent Juvenile Crime." Crime and Delinquency 40: 96-104. http://dx.doi.org/10.1177/0011128794040001007

Johnson, B. R., M. E. Pagano, Matthew T. Lee, and Stephen G. Post. 2015. "Alone on the Inside: Social Isolation, Social Support, and the Drink-Trouble Cycle?" Youth and Society (in press).

Kelly, J. F., M. E. Pagano, R. L. Stout, and S. M. Johnson. 2011. "Influence of Religiosity on 12-Step Participation and Treatment Response Among Substance-Dependent Adolescents." Journal of Studies on Alcohol and Drugs 72: 1000-1011. http://dx.doi.org/10.15288/jsad.2011.72.1000

Kennedy, D. M. 2008. Deterrence and Crime Prevention: Reconsidering the Prospect of Sanction. New York, NY: Routledge.

King, R. S. and J. Pasquarella. 2009. Drug Courts: A Review of the Evidence. Washington, DC: The Sentencing Project.

Krisberg, B. 2001. The Plight of Children Whose Parents are in Prison. Oakland, CA: National Council on Crime and Delinquency, Focus.

Langan, P. and D. Levin. 2002. Recidivism of Prisoners Released in 1994. Bureau of Justice Statistics. Recidivism of Released Prisoners Series, NCJ 193427, http://www.bjs.gov/index. cfm?ty $=$ pbdetail \&iid $=1134$

LaVigne, N. and J. Samuels. 2012. The Growth \& Increasing Cost of the Federal Prison System: Drivers and Potential Solutions. Washington, DC: The Urban Institute.

Lee, M. T., M. E. Pagano, B. R. Johnson, and S. G. Post. 2016. "Love and Service in Adolescent Addiction Recovery." Alcohol Treatment Quarterly 34(2): 197-222. http://dx.doi.org/10.1080/07347324.2016.1148513

Lee, M. T., P. S. Veta, B. R. Johnson, and M. E. Pagano, M.E. (2014). "Daily Spiritual Experiences and Adolescent Treatment Response." Alcohol Treatment Quarterly 32 (2): 290-317. http://dx.doi.org/10.1080/07347324.2014.907029

Lutze, F. E. and J. van Wormer. 2007. "The Nexus Between Drug and Alcohol Treatment Program Integrity and Drug Court Effectiveness." Criminal Justice Policy Review 18 (3): 226-245. http://dx.doi.org/10.1177/0887403406302327

Lipsey, M. W. 1992. "Juvenile Delinquency Treatment: A MetaAnalytic Inquiry into the Variability of Effects." In MetaAnalysis for Explanation: A Casebook, edited by T. D. Cook, H. Cooper, D. S. Cordray, H. Hartmann, L.V. Hedges, R. J. Light, T.A. Louis, and F. Mosteller. New York: Russell Sage Foundation.

MacKenzie, D. 2006. What Works in Corrections: Reducing the Criminal Activities of Offenders and Delinquents. New York, NY: Cambridge University Press. http://dx.doi.org/10.1017/CBO9780511499470 
Maruna, S. 2001. Making Good: How Ex-Convicts Reform and Rebuild Their Lives. Washington, DC: American Psychological Association. http://dx.doi.org/10.1037/10430-000

Maruna, S. and T. P. LeBel. 2003. "Welcome Home? Examining the 'Reentry Court' Concept from a Strengths-based Perspective." Western Criminology Review 4:91-107.

McClelland, G.M., K. S. Elkington, L. A. Teplin, and K. M. Abram, K.M. 2004a. "Multiple substance use disorders in juvenile detainees." Journal of the American Academy of Child Adolescent Psychiatry 43(10):1215-1224. http://dx.doi.org/10.1097/01.chi.0000134489.58054.9c

McClelland, G.M.; L. A. Teplin, and K. M. Abram. 2004b. "Detection and prevalence of substance use among juvenile detainees." Juvenile Justice Bulletin. Washington, DC: U.S. Department of Justice, Office of Juvenile Justice and Delinquency Prevention.

Miller, J. W., T. S. Naimi, R. D. Brewer, S. E. Jones. 2007. "Binge Drinking and Associated Health Risk Behaviors among High School Students." Pediatrics, 119: 76-85. http://dx.doi.org/10.1542/peds.2006-1517

Miniño, A. M., J. Xu, and K. D. Kochanek. 2010. Deaths: Preliminary Data for 2008. National Vital Statistics Reports, 59 (2): 1-52.

Mitchell, O., D. B. Wilson, A. Eggers, and D. L. MacKenzie. 2012. "Assessing the Effectiveness of Drug Courts on Recidivism: A Meta-analytic Review of Traditional and Non-traditional Drug Courts." Journal of Criminal Justice 40: 60-71. http://dx.doi.org/10.1016/j.jcrimjus.2011.11.009

Morris, N. and M. Tonry, M. 1991. Between Prison and Probation: Intermediate Punishments in a Rational Sentencing System. New York, NY: Oxford University Press.

Mumola, C. J. and J. C. Karberg. 2006. "Drug Use and Dependence, State and Federal Prisoners, 2004," (Washington, DC: US Dept. of Justice, Oct. 2006) (NCJ213530), p. 7. http://dx.doi.org/10.1037/e560272006-001

Neighbors, B., T. Kempton and R. T. Forehand. 1992. "Cooccurrence of Substance Abuse with Conduct, Anxiety, and Depression Disorder in Juvenile Delinquents." Addictive Behaviors, 17: 379-386. http://dx.doi.org/10.1016/0306-4603(92)90043-U

Office of the Surgeon General. (2007). NSDUH Report. The Surgeon General's Call to Action to Prevent and Reduce Underage Drinking. Rockville, MD: USDHHS.

Pagano, M. E., Zeltner, B. B., Jaber, J., Post, S. G., Zywiak, W. H., \& Stout, R. L. (2009). "Helping Others and Long-Term Sobriety: Who Should I Help to Stay Sober?" Alcoholism Treatment Quarterly 27: 38-50. http://dx.doi.org/10.1080/07347320802586726

Pagano, M. E., Krentzman, A. R., Onder, C. C., Baryak, J. L., Murphy, J. L., Zywiak, W. H., \& Stout, R. L. (2010). "Service to Others in Sobriety (SOS)," Alcoholism Treatment Quarterly 28: 111-127. http://dx.doi.org/10.1080/07347321003656425

Pagano, M. E., White, W. L., Kelly, J. F., Stout, R. L., \& Tonigan, J. S. (2013a). 10-year course of Alcoholics Anonymous participation and long-term outcomes: A follow-up study of outpatient subjects in Project MATCH. Substance Abuse 34: 51-59.

http://dx.doi.org/10.1080/08897077.2012.691450

Pagano M. E., Kelly, J. F., Scur, M. D., Ionescu, R. A., Stout, R. L., Post, S. G. (2013b). "Assessing Youth Participation in AArelated Helping: Validity of the Service to Others in Sobriety (SOS) Questionnaire in an Adolescent Sample." American Journal of Addiction 22: 60-66. http://dx.doi.org/10.1111/j.1521-0391.2013.00322.x

Pagano, M.E., Wang, A. R., Rowles, B. M., Lee. M. T., \& Johnson, B. R. (2015). "Social Anxiety and Peer-Helping in Adolescent Addiction Treatment" Alcoholism: Clinical and Experimental Research 39:887-895. http://dx.doi.org/10.1111/acer.12691
Petersilia, J. 1997. Community Corrections: Probation, Parole, and Intermediate Sanctions. New York, NY: Oxford University Press.

Petersilia, J. 2009. When Prisoners Come Home: Parole and Prisoner Reentry. New York, NY: Oxford University Press. http://dx.doi.org/10.1093/acprof:oso/9780195160864.001.000 1

Petrosino, A., C. T. Petrosino, and J. Buehler. 2004. "Scared Straight" and Other Juvenile Awareness Programs for Preventing Juvenile Delinquency. Campbell Systematic Reviews 2: 1-62. The Campbell Collaboration.

Ronel, N. and E. Elisha. 2011. "A Different Perspective: Introducing Positive Criminology." International Journal of Offender Therapy and Comparative Criminology 55(2):305-325. http://dx.doi.org/10.1177/0306624X09357772

Ronel, N. and D. Segev (eds). 2015. Positive Criminology. New York: Routledge.

Singer, S. I. and D. McDowall. 1988. "Criminalizing Delinquency: The Deterrent Effects of the New York Juvenile Offender Law." Law and Society Review 22:521-35. http://dx.doi.org/10.2307/3053628

Statement of Principles (2011). Austin, Texas: Right on Crime.

Sourcebook of Criminal Justice Statistics Online (2010). State University New York at Albany, http://www.albany.edu/sourcebook/pdf/t192010.pdf.

Straussner, S. L. A. and H. Byrne. 2009. "Alcoholics Anonymous: Key Research Findings from 2002-2007." Alcoholism Treatment Quarterly 27:349-367. http://dx.doi.org/10.1080/07347320903209665

Substance Abuse and Mental Health Services Administration, Center for Behavioral Health Statistics and Quality. 2014. The TEDS Report: Age of Substance Use Initiation among Treatment Admissions Aged 18 to 30. Rockville, MD.

Thompson, G. J. and J. B. Jenkins. 1993. Verbal Judo: The Gentle Art of Persuasion. William Morrow and Company, Inc, New York.

Tonigan, J. S. and M. P. Bogenschutz. 2008. "Utilization of formal treatment and AA: Relative contributions to early abstinence." Alcoholism: Clinical \& Experimental Research: Supplement 32 (6): 695.

Turney, K. and Wildeman, C. 2013. "Redefining Relationships: Explaining the Countervailing Consequences of Paternal Incarceration for Parenting Quality." American Sociological Review 78: 949-979. http://dx.doi.org/10.1177/0003122413505589

Travis, J., B. Western, and S. Redburn. 2014. The Growth of Incarceration in the United States: Exploring Causes and Consequences. (Editors). National Research Council. Washington, D.C.: The National Academies Press.

Wakefield, S. and C. Wildeman. 2013. Children of the Prison Boom: Mass Incarceration and the Future of American Inequality. New York, NY: Oxford University Press. http://dx.doi.org/10.1093/acprof:oso/9780199989225.001.000 1

Wang, E. A. and C. Wildeman. 2011. "Studying Health Disparities by Including Incarcerated and Formerly Incarcerated Individuals," JAMA 305:1708-1709. http://dx.doi.org/10.1001/jama.2011.532

Wildeman, C. 2010. "Paternal Incarceration and Children's Physically Aggressive Behaviors: Evidence from the Fragile Families and Child Wellbeing Study," Social Forces 89: 285-310. http://dx.doi.org/10.1353/sof.2010.0055

Wildeman, C. 2014. "Parental Incarceration, Child Homelessness, and the Invisible Consequences of Mass Imprisonment." ANNALS of the American Academy of Political and Social Science 651:74-96. http://dx.doi.org/10.1177/0002716213502921 
Wildeman, C. and C. Muller. 2012. "Mass Imprisonment and Inequality in Health and Family Life." Annual Review of Law and Social Science 8:11-30. http://dx.doi.org/10.1146/annurev-lawsocsci-102510-105459

Wildeman, C. and B. Western. 2010. "Incarceration in Fragile Families." The Future of Children 20:157-177. http://dx.doi.org/10.1353/foc.2010.0006

Wilson, D. B., D. L. MacKenzie, F. N. Mitchell. 2008. "Effects of Correctional Boot Camps on Reoffending." Campbell Systematic Reviews 1: 12.
Wormer, J. and F. Lutze. 2010. "Managing and Sustaining Your Juvenile Drug Court." Juvenile and Family Court Journal 61(2). http://dx.doi.org/10.1111/j.1755-6988.2010.01041.x

Zimmerman, P., H. U. Wittchen, M. Hofler, H. Pfister, R. C. Kessler, and R. Lieb. 2003. "Primary Anxiety Disorders and the Development of Subsequent Alcohol Use Disorders: A 4Year Community Study of Adolescents and Young Adults." Psychological Medicine 33: 1211-1222. http://dx.doi.org/10.1017/S0033291703008158

Received on 04-05-2016 Accepted on 17-06-2016

Published on 28-09-2016

DOI: http://dx.doi.org/10.6000/1929-4409.2016.05.16

(c) 2016 Johnson et al.; Licensee Lifescience Global.

This is an open access article licensed under the terms of the Creative Commons Attribution Non-Commercial License (http://creativecommons.org/licenses/by-nc/3.0/) which permits unrestricted, non-commercial use, distribution and reproduction in any medium, provided the work is properly cited. 